\title{
Oral squamous cell carcinoma of tongue: Histological risk assessment. A pilot study
}

\author{
Blanca del Carmen Migueláñez-Medrán ${ }^{1}$, José-Juan Pozo-Kreilinger ${ }^{2}$, José-Luis Cebrián-Carretero ${ }^{3}$, \\ Miguel-Ángel Martínez-García ${ }^{4}$, Antonio-Francisco López-Sánchez ${ }^{5}$
}

\author{
${ }^{1}$ PhD. Associate Professor of Preventive and Community Dentistry. URJC. Madrid (Spain) \\ ${ }^{2}$ PhD. Associate Professor of Medicine. Department of Pathology. UAM. Madrid (Spain) \\ ${ }^{3}$ PhD. Associate Professor of Medicine. UAM. Madrid (Spain). Head of Maxillofacial Surgery Service. Universitary Hospital of \\ La Paz. Madrid (Spain) \\ ${ }^{4} \mathrm{PhD}$. Visiting Professor of Pharmacology. URJC. Madrid (Spain) \\ ${ }^{5} \mathrm{PhD}$. Associate Professor of Oral Medicine. URJC. Madrid (Spain)
}

Correspondence:

Faculty of Odontology. Rey Juan Carlos University

Avenida de Atenas s/n 28922 Alcorcón, Madrid (Spain)

blancac.miguelanez@urjc.es

Received: 28/01/2019

Accepted: $22 / 04 / 2019$

\author{
Migueláñez-Medrán BC, Pozo-Kreilinger JJ, Cebrián-Carretero JL, \\ Martínez-García MA, López-Sánchez AF. Oral squamous cell carcinoma \\ of tongue: Histological risk assessment. A pilot study. Med Oral Patol \\ Oral Cir Bucal. 2019 Sep 1;24 (5):e603-9. \\ http://www.medicinaoral.com/medoralfree01/v24i5/medoralv24i5p603.pdf \\ Article Number: 23011 http://www.medicinaoral.com \\ (C) Medicina Oral S. L. C.I.F. B 96689336 - pISSN 1698-4447 - eISSN: $1698-6946$ \\ eMail: medicina@medicinaoral.com \\ Indexed in: \\ Science Citation Index Expanded \\ Journal Citation Reports \\ Index Medicus, MEDLINE, PubMed \\ Scopus, Embase and Emcare \\ Indice Médico Español
}

\begin{abstract}
Background: More than $90 \%$ of malignant tumors diagnosed in the oral cavity are Oral Squamous Cell Carcinomas (OSCC) whose preferred location is the tongue. Classically, this disease has affected men preferentially, although recent studies suggest that trends are changing and the proportion of women with OSCC is increasing. In addition, the prevalence of oral cancer is also determined by some risk factors as alcohol consumption and tobacco. Currently, the Tumor, Node, Metastasis (TNM) classification is employed to defined tumor stage and based on this guide specific treatments are established. However, 5-year-survival does not exceed $50 \%$ of cases. The objective of this study is to determine whether a histological risk pattern indicative of higher recurrence might be present in T1-T2 tumors located in the anterior two thirds of the tongue.

Material and Methods: Samples from 26 patients with OSCC were analyzed and histological risk pattern of recurrent and non-recurrent tumors were compared. We have analyzed histological variables described in Anneroth and Brandwein-Gensler classifications. Additionally, we have also examined both clinical variables such as age, sex or comorbidities, as well as habits such as tobacco or alcohol consumption.

Results: We found that sex (male) and keratinization degree (high or moderate) are directly related with OSCC recurrence. In fact, free illness time is lower in men and higher in those cases with minimal or no keratinization. Conclusions: Based on the variables analyzed, it has not been possible to establish a histological risk pattern that, complementary to the TNM classification, could have a predictive role in these early-stage tongue carcinomas.
\end{abstract}

Key words: Oral cancer, oral squamous cell carcinoma, histologic risk assessment, oral cancer recurrence. 


\section{Introduction}

Approximately 300.373 new cases of oral squamous cell carcinoma (OSCC) are annually reported around the world (1), what makes oral cancer the sixth most common cancer worldwide $(2,3)$.

The term oral cancer is referred to as a subgroup of head and neck malignant neoplasms affecting the lips, the anterior two-thirds of tongue, the salivary glands, the gingiva, the floor of the mouth, the oral mucosal surface and the palate (2), with the tongue being the most common location $(3,4)$.

The peak incidence occurs after the fifth decade of life, most commonly between the sixth and eight decade in men, and rarely in patients under 40 years of age $(5,6)$. Yet, current studies reveal a rise in the incidence in this latter group of young patients $(7,8)$.

The main risk factors for the onset of oral carcinoma are: tobacco and alcohol consumption (both of which a synergistic effect), betel nut, certain dietetic habits, genetic factors, sun exposure, poor oral hygiene and human papillomavirus (HPV)infection $(9,7,6,10,11-18)$.

-Justification and objectives

The tumour, nodes and metastases classification of malignant tumours (TNM classification) has been used for decades to estimate the prognosis and survival of oral cancer patients, besides providing guidance on the treatment regimen to be followed in each case of OSCC. Notwithstanding, a great number of T1N0M0 and T2N0M0 stage patients do not respond as expected to the treatment proposed for the stage assigned to their cancer (19).

A unique surgical approach is usually aimed for earlystage tumours (T1-T2). Although coadjuvant treatment is not considered necessary for this kind of tumours $(20,21)$, locoregional recurrence is actually expected in $25-37 \%$ of cases. Hence, tumour resection with adequate surgical margins is in some occasions not considered the optimal definitive treatment for such kind of tumours $(22,23)$.

The aim of the present study is first to determine whether a specific histologic pattern exists for those recurrent cases ofT1/T2 SCC of the tongue submitted exclusively to surgical treatment. Secondly, to envisage whether the variables analysed can affect independently to the recurrence risk in those patients with SCC of the tongue. And thirdly, to evaluate the disease-free survival considering those factors associated to an increased recurrence risk for cancer.

\section{Material and Methods}

A detailed clinical and laboratory study was performed on 26 patients with SCC of the anterior tongue, diagnosed between years 2000 to 2015 . The sample was composed of 18 men and 8 women with ages comprised between 33 and 90. All cases diagnosed as
OSCC;WHO's International Classification of Diseases for Oncology (ICD-O) code 8070/3 (24).

Two groups were distinguishable (13 patients each):

1) A case group consisting of patients with T1-T2 tumours with no suspicion of lymph node involvement at the moment of diagnosis but presenting tumour recurrence after exclusively surgical treatment of cancer of the tongue.

2) A control group including patients with T1-T2 tumours with no suspicion of lymph node involvement at the moment of diagnosis,with no recurrence and hence, as presumed, responding positively to the corresponding surgical treatment.

All samples included $\geq 5 \mathrm{~mm}$ disease-free margins.

In order to ensure the ethical principle of confidentiality, a coding system was used to preserve the anonymity of the patients. Patients' personal data, toxic habits and relevant medical history as well as clinical data and anatomopathological information of the lesion under study were registered. In this regard, the study obtained the approval of La Paz University Hospital Research Ethics Committee (Madrid).

To determine the histologic grade (malignancy), Anneroth's and Brandwein-Gensler's classification systems were used $(22,25)$.

All samples were analysed by two independent researchers: an experienced anatomopathologist (J.J.P) and a co-worker with histopathological examination skills (B.C.M), who identified the tumour front for each sample. Each factor was compared on the dependent variable (recurrence) using 1) thechi-square test of independence -significance, at least for $\mathrm{p}<.05$, indicates a relationship between the factor and the dependent variable-and 2) a binary logistic regression procedure-to estimate the value of odds ratio (OR) for the risk of recurrence-.That is, a univariate analysis of the effect on recurrence for each factor separately was conducted. To compare dichotomous factors, Fisher's test was used instead of the cited chi-square test.

\section{Results}

First, the effect of the characteristics of the sample on tumour recurrence was analysed. Since all the possible explanatory factors for recurrence were dichotomous, inferential (Fisher's test) statistics were generated.

Variables showed that there was a statistically significant higher risk of tumour recurrence in men than in women. Moreover, increased risk was particularly found in patients with one of the following characteristics: aged under 50, tobacco or alcohol users, arterial hypertension (AHT), heart disease and tumour size $>$ $2 \mathrm{~cm}$ but $\leq 4 \mathrm{~cm}$.

Effect of the variables defined in Anneroth's classification on recurrence: The results of such comparisons are shown in Table 1. 
Table 1: Bivariate inferential analysis. Univariate effect of the variables defined in ANNEROTH's classification on recurrence $=$ Yes. Chi-square test of independence or Fisher's test and logistic regression.

\begin{tabular}{|c|c|c|c|c|c|c|c|c|c|}
\hline \multirow{2}{*}{ Variable } & \multirow[b]{2}{*}{ Category } & \multicolumn{2}{|c|}{ RECURRENCE } & \multicolumn{2}{|c|}{$\begin{array}{c}\text { Chi-square / } \\
\text { Fisher's }\end{array}$} & \multirow[b]{2}{*}{ P-Sig } & \multirow[b]{2}{*}{$\begin{array}{l}\text { Odds } \\
\text { Ratio }\end{array}$} & \multirow[b]{2}{*}{$\begin{array}{l}\text { Lower } \\
\text { limit }\end{array}$} & \multirow[b]{2}{*}{$\begin{array}{l}\text { Upper } \\
\text { limit }\end{array}$} \\
\hline & & YES & NO & Value & P-Sig & & & & \\
\hline \multirow{3}{*}{$\begin{array}{l}\text { Degree of } \\
\text { keratinizati } \\
\text { on }\end{array}$} & High & $61.5 \%^{8}$ & $38.5 \%^{5}$ & \multirow[t]{3}{*}{8.14} & \multirow[t]{3}{*}{$.017 *$} & -- & -- & -- & -- \\
\hline & moderate & $62.5 \%^{5}$ & $37.5 \%^{3}$ & & & -- & -- & -- & -- \\
\hline & low/none & $0 \%{ }^{--}$ & $100 \%^{5}$ & & & - & - & - & - \\
\hline \multirow{2}{*}{$\begin{array}{l}\text { Nuclear } \\
\text { polymorphi } \\
\text { sm }\end{array}$} & Little/moderate & $41.7 \%^{5}$ & $58.3 \%^{7}$ & \multirow[t]{2}{*}{--} & \multirow[t]{2}{*}{$.695^{\mathrm{NS}}$} & - & - & - & - \\
\hline & $\begin{array}{l}\text { abundant/extre } \\
\text { me }\end{array}$ & $57.1 \%^{8}$ & $42.9 \%{ }^{6}$ & & & $.433^{\mathrm{NS}}$ & 1.87 & 0.39 & 8.89 \\
\hline \multirow{2}{*}{$\begin{array}{l}\text { Mitosis /10 } \\
\text { fields }\end{array}$} & 1 to 5 & $50 \%^{2}$ & $50.0 \%^{2}$ & \multirow[t]{2}{*}{--} & \multirow[t]{2}{*}{$1^{\mathrm{NS}}$} & -- & -- & -- & -- \\
\hline & more than 5 & $50.0 \%{ }^{11}$ & $50.0 \%{ }^{11}$ & & & -- & -- & -- & -- \\
\hline \multirow[t]{3}{*}{$\begin{array}{l}\text { Pattern of } \\
\text { invassion }\end{array}$} & $\begin{array}{l}\text { tentacular/expan } \\
\text { sive }\end{array}$ & $57.1 \%^{8}$ & $42.9 \%{ }^{6}$ & \multirow[t]{3}{*}{0.95} & \multirow[t]{3}{*}{$.621^{\mathrm{NS}}$} & $.337^{\mathrm{NS}}$ & 2.67 & 0.36 & 19.71 \\
\hline & $\begin{array}{l}\text { tumournests }>15 \\
\text { cells }\end{array}$ & $50.0 \%{ }^{3}$ & $50.0 \%{ }^{3}$ & & & $.560^{\mathrm{NS}}$ & 2.00 & 0.19 & 20.61 \\
\hline & $\begin{array}{l}\text { Tumour } \\
\text { nests }<15 \text { cells }\end{array}$ & $33.3 \%^{2}$ & $66.7 \%{ }^{4}$ & & & - & - & - & - \\
\hline \multirow[t]{2}{*}{$\begin{array}{l}\text { Stage of } \\
\text { invasion }\end{array}$} & $\begin{array}{l}\text { Exclusive } \\
\text { invasión lamina } \\
\text { propria }\end{array}$ & $0 \%$ & $100 \%^{3}$ & \multirow[t]{2}{*}{-} & \multirow[t]{2}{*}{$.220^{\mathrm{NS}}$} & - & - & - & - \\
\hline & $\begin{array}{l}\text { Underlying } \\
\text { muscular } \\
\text { invasion }\end{array}$ & $\begin{array}{l}56.5 \%^{1} \\
3\end{array}$ & $43.5 \%{ }^{10}$ & & & -- & -- & -- & -- \\
\hline \multirow{3}{*}{$\begin{array}{l}\text { Lymphopla } \\
\text { smocytic } \\
\text { infiltration }\end{array}$} & abundant & $66.7 \%^{6}$ & $33.3 \%^{3}$ & \multirow[t]{3}{*}{1.76} & \multirow[t]{3}{*}{$.415^{\mathrm{NS}}$} & $.215^{\mathrm{NS}}$ & 4.00 & 0.45 & 35.79 \\
\hline & moderate & $45.5 \%^{5}$ & $54.5 \%{ }^{6}$ & & & $.629^{\mathrm{NS}}$ & 1.67 & 0.21 & 13.22 \\
\hline & mild/absence & $33.3 \%^{2}$ & $66.7 \%{ }^{4}$ & & & - & - & - & - \\
\hline \multirow[t]{3}{*}{ Score } & grade $1(\leq 15)$ & $60.0 \%{ }^{9}$ & $40.0 \%{ }^{6}$ & 1.89 & $.390^{\mathrm{NS}}$ & $.181^{\mathrm{NS}}$ & 3.75 & 0.54 & 26.04 \\
\hline & grade $2(16-18)$ & $28.6 \%^{2}$ & $71.4 \%^{5}$ & & & - & - & - & - \\
\hline & grade $3(\geq 19)$ & $50.0 \%{ }^{2}$ & $50.0 \%{ }^{2}$ & & & $.482^{\mathrm{NS}}$ & 2.50 & 0.19 & 32.19 \\
\hline
\end{tabular}

To summarise, only the relationship between recurrence and moderate-high degree of keratinization was proved to be statistically significant Effect of the variables defined in Brandwein -Gensler's classification on tumour recurrence: The results obtained from such comparisons are presented in Table 2.
None of the analyzed variables shown statistical significance. Same statistical methodology as described in the previous section was used.

Multivariate effects on recurrence:

The statistical analysis of the univariate effects on recurrence proved the statistically significant relationship 
Table 2: Bivariate inferential analysis. Univariate effect of the variables defined in BRANDWEIN-GENSLER's classification on recurrence $=$ Yes. Chi-square test of independence or Fisher's test and logistic regression.

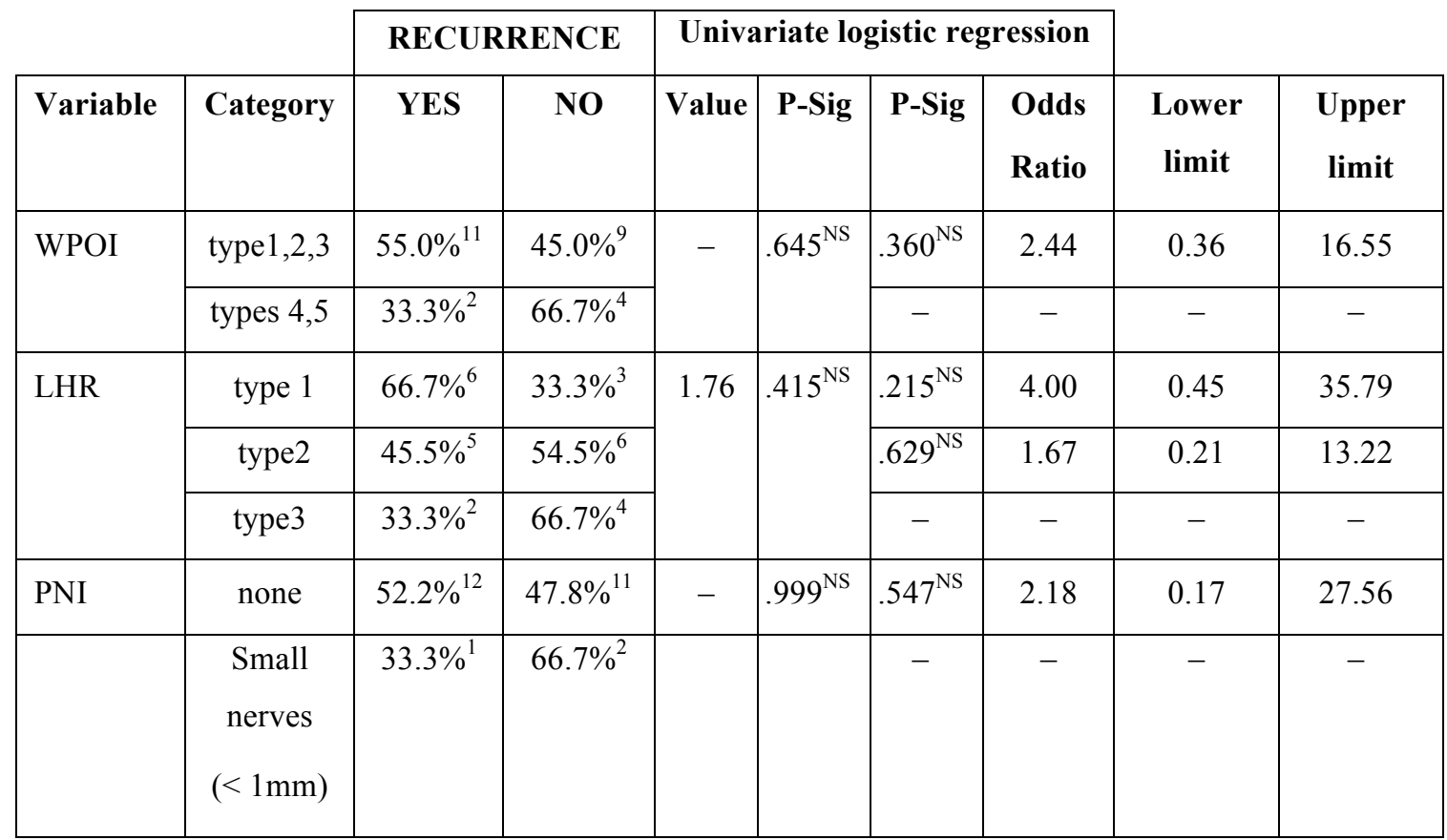

WPOI: worst patron of invasion. LHR: lymphocytic host response. PNI: perineural invasion.

between recurrence and gender (men) or degree of keratinization (moderate and high).

Other factors that showed a positive although not statistically significant trend towards tumour recurrence were: tobacco or alcohol consumption, AHT, T2 tumours (tumour size according to TNM classification), abundant/extreme nuclear pleomorphism, tentacular/ expansive invasion pattern, abundant lymphoplasmocytary infiltrate, worst pattern of invasion type 1, 2 or 3 and pronounced lymphocytic host response.

The initial aim of the statistical study was to build a multivariate model predictive of recurrence. Strictly, this model can only be built with the two significant factors afore mentioned: gender and degree of keratinization. But factors categorised as suspicious could also be added one at a time to them. Although in large samples it may be possible to achieve a multivariate model, in small samples it is more complicated.

\section{Discussion}

OSCC is the most common carcinoma affecting the oral cavity and comprises over $90 \%$ of all oral tumours 9,26 , with the tongue as one of the most frequent sites of presentation (27).

The average age in the present study was 63.8 and included 26 participants, of whom 18 were men (69.2\%) and 8 women $(30.8 \%)$. Men showed a statistically significant higher risk of recurrence $(p<0.5)$ than women. In this regard, Garavello et al. (28) have reported in a study performed on 213 patients that there is no rela- tionship between gender and prognosis. Likely, despite it being a study on both tongue and floor of the mouth, Amaral et al. (29) have indicated that the recurrence rate does not differ between gender groups.

The TNM classification system has been used for several years to determine the kind of therapy to be used and the response to such treatment, as well as to predict the survival of patients with OSCC $(24,30)$. Tongue squamous cell carcinoma is one of the most aggressive tumours in behaviour. Even at early stages may the patient need to be submitted to a treatment plan consisting of radio/chemotherapy besides surgical removal of the tumour (31). There may be therefore a group of patients with stage I and II tumours who suffer from constant recurrent events despite being treated accordingly to their stage and who even die because of their illness. Hence the idea of developing histological classifications. Most of these classifications are based on modifications of Jakobsson et al's (32) and follow a two-folded purpose: (1) to explain why two tumours with identical clinical characteristics can lead to different biological behaviours; (2) to complete the prognostic value of TNM classification. The challenge is to find the most suitable treatment for each patient, according to the specific characteristics of the tumour $(30,31)$.

All samples analysed in this study had appropriate surgical excision margins $(\geq 5 \mathrm{~mm})$, since inappropriate margins could imply higher tumour recurrence rates33. However, other authors like Spiro and cols (34) have considered that these margins do not have such importance, 
given that recurrence can happen in those tumours being excised with safety margins as well as in those tumours excised with none, as they expose in their study. In fact, they highlight that local control of the disease (absence of recurrence) is also achieved in some tumours with positive margins being treated with radiotherapy.

Anneroth's classification (25) proposed in 1987 introduced a multiparametric classification system in which the tumoral tissue was evaluated based on the histological characteristics of the tumour itself, as well as on the relationship resulting from the interaction between tumour and host. In the study here in, the variables defined in Anneroth's classification were first analysed in order to describe if any of them, single-handedly or in combination with others, possessed a significant prognostic value. According to Anneroth (25) the degree of keratinization is one of the parameters that indicate the differentiation of the tumour cell population. In this line, in the present study no case in absence or with little keratinization was found to be recurrent. On the contrary, those cases with moderate or high keratinization were indeed recurrent $(p<0.5)$. Just precisely, Odell et al35have concluded that keratinization is one of the histopathologic characteristics more related to both local recurrence and risk of metastasis. Moreover, in a study performed by Acharya et al. (7), the differences existing between risk factors and histopathological characteristics were analysed in two population groups of different age ranges. When the variables defined in Anneroth's classification were independently analysed, the degree of keratinization was found to be higher in younger patients. Nevertheless, this could be due to the fact that besides the typical forms of tobacco, chewed tobacco was also considered (the study was performed in India, where this type of practice is common). In this respect, Woolgar et al. (36), in an attempt to enhance the reproducibility of this parameter, modified the way the degree of keratinization was assessed: tumours with high keratinization were classified according to the number and appearance of keratin pearls, whereas those less keratinized were classified according to individual cell keratinization. In addition, they pointed that the degree of keratinization may have an independent prognostic value and they reflected it with a useful variable of the classification systems of the histological risk. Just opposite these statements, in 2009 Weijers et al. (37) reported that none of the components of Anneroth's model had demonstrated to have a higher predictive value than any other. Eventually, contrary to the studies aforementioned, Sawair et al. (38) have not found any association between the degree of keratinization and the onset of local recurrence, despite having considered this parameter one of the most reproducible. Moreover, they have argued that the state of resection margins is a more important factor as regards tumour recurrence.
Brandwein-Gensler and cols (22) suggested a system of histological risk in which the most aggressive pattern of infiltration, the lymphocyte host response and the perineural invasion are evaluated. Subsequently, different scores were assigned to each variable according to the category, being tumours classified as high-, intermediate- or low-risk.

In agreement with the results obtained when evaluating the different variables defined in Anneroth's classification, the worst recurrent rates were found in those patients with a worst pattern of invasion (WPOI) type 1,2 and 3. Other authors such as Li and cols (39) have however suggested that the sole presence of a WPOI type 5 could be indicative of a high risk carcinoma and estimated a probability of $42 \%$ for loco-regional recurrence. But if carcinoma is considered as high-risk (a score of 3 or more) resulting from the sum of scores obtained by the different variables analysed, the probability of local recurrence reduces to $32 \%$.

Lymphocyte host response (LHR) is considered the result of the interaction between host and tumour. In accordance with what previously exposed for Anneroth's classification, LHR type 3 corresponds to a weakened immune response to tumour invasion and however accounts for the lowest recurrence rate in our sample. In clear opposition, Melekiand cols 40 have suggested that a more pronounced LHR is related to a better result to the treatment, since the immune activity may exert a protective effect on the patient. This latter is in keeping with what described by the authors of the classification (22), who show in their work that a limited or weak LHR is associated with increased local recurrence.

The authors (22) of the classification indicate that perineural invasion (PNI) in both small and large nerves is associated to a greater risk of local recurrence. According to this, Chatzistefanou et al. (41) have stated that the presence of perineural invasion is considered a negative prognostic factor if related to the patient's survival. However it is not possible for us to provide any conclusive information about this variable due to the characteristics of our sample, since only one out of the three patients that displayed perineural invasion suffered from recurrence. Studies carried out by Woolgar et al. $(36,42,43)$ have shown that tumour infiltration into the perineural space at the tumour invasion front is related to tumour diameter, width, invasion pattern, existence of nodal metastasis, state of the margins of resection and individual survival.

Generally speaking, it appears that there is no consensus on the predictive value of malignant histological classifications in some cases. In fact, certain studies $(31,37,44,45)$ have demonstrated the inability of these classifications to predict the prognostic outcome of small-size carcinomas. The results presented herein confirm however some of the cases cited above and sug- 
gest that it may be possible to ensure a positive trend of the effect on recurrence associated to gender and degree of keratinisation in larger sample sizes. So it is the probability of including some other factors in the predictive model, such as tobacco and alcohol consumption, abundant-extreme nuclear pleomorphisms and $\mathrm{T} 2$ tumours size. As various authors have argued, it seems that tongue squamous cell carcinomas exhibit an aggressive behaviour in earlier stages of the disease for unknown reasons. In fact, they cause higher mortality rates than any early-stage tumours in other sites of the oral cavity $(31,46,47)$.

According to Almangush and cols (45) the tongue has a variety of structural characteristics that make it possible to influence the way tumour disseminates: it is composed of muscle bundles and has a rich network of lymphatic vessels.

No reproducible prognostic predictors have been identified in the assessment of OSCC despite the emergence of recent studies based on cell morphometry, flow cytometry and oncogenic expression -like the ones carried out by Odell and cols (35).

As a conclusion, various authors $(34,48)$ agree in the importance of implementing histological classifications as additional tools for the diagnosis of OSCC and its recurrence. However, biological markers must be sought to describe and predict the tumour's behaviour.

\section{References}

1. Slam P, Gale N, Hunter K, Lingen M, Nylander K et al. Malignant surface epithelial tumours. In: El-Naggar AK, Chan JKC, Grandis JR, Takata T, Slootwe PJ. WHO classification of Head and Neck Tumours. 4th ed. Lyon: IARC Press; 2017. p 109-11.

2. Tsantoulis PK, Kastrinakis NG, Tourvas AD, Laskaris G, Gorgoulis VG. Advances in the biology of oral cancer. Oral Oncol. 2007; 43:523-34.

3. de Camargo Cancela M, Volti L, Guerra-Yi M, Chapuis F, Mazuir M, Curado MP. Oral cavity cancer in developed and in developing countries: population based incidence. Head Neck. 2010;32:357-67.

4. Bello IO, Soini Y, Salo T. Prognostic evaluation of oral tongue cancer: Means, markers, and perspectives (I). Oral Oncol. 2010;46:6305.

5. Sasaki T, Moles DR, Imai Y, Speight PM. Clinico-pathological features of squamous cell carcinoma of the oral cavity in patients < 40 years of age. J Oral Pathol Med. 2005;34:129-33

6. Llewellyn CD, Johnson NW, Warnakulasuriya KA. Risk factors for oral cancer in newly diagnosed patients aged 45 years old and younger: a case-control study in Southern England. J Oral Pathol Med. 2004;33:525-32.

7. Acharya S, Tayaar AS. Analysis of clinical and histopahological profiles of oral squamous cell carcinoma in young Indian adults: A retrospective study. J Dent Sci. 2012;7:224-30.

8. Ribeiro AC, Silva AR, Simonato LE, Salzedas LM, Sundefeld ML, Soubhia AM. Clinical and histopathological analysis of oral squamous cell carcinoma in young people: a descriptive study in Brazilians. Br J Oral Maxillofac Surg. 2009;47:95-8

9. Scully C, Bagan J. Oral squamous carcinoma overview. Oral Oncol. 2009;45:301-8

10. Llewellyn CD, Johnson NW, Warnakulasuriya KA. Risks factors for squamous cell carcinoma of the oral cavity in young people- a comprehensive literature review. Oral Oncol. 2001;37:401-18.

11. Mayne ST, Morse DE, Winn DM. Cancers of the oral cavity and pharynx. In: Schottenfeld D, Fraumeni JF. Cancer Epidemiology and Prevention. New York: Oxford University Press; 2006.p.674-96.

12. Chitapanarux I, Lorvidhaya V, Sittitrai P, Pattarasakulchai T, Tharavichitkul E, Sriuthaisiriwong P et al. Oral cavity cancers at a young age: analysis of patient, tumor and treatment characteristics in Chiang Mai University Hospital. Oral Oncol. 2006;42:82-7.

13. Warnakulasuriya S, Sutherland G, Scully C. Tobacco, oral cancer, and treatment of dependence. Oral Oncol. 2005;41:244-60.

14. Ogden GR. Alcohol and oral cancer. Alcohol. 2005;35:169-73.

15. Nair U, Bartsch H, Nair J. Alert for an epidemic of oral cancer due to use of the betel quid substitutes gutkha and pan masala: a review of agents and causative mechanisms. Mutagenesis. 2004;19:251-62.

16. Gupta PC, Ray CS. Smokeless tobacco and health in India and South Asia. Respirology. 2003;8:419-31.

17. Bagan JV, Scully C. Recent advances in oral oncology 2007 epidemiology, aetiopathogenesis, diagnosis and prognostication. Oral Oncol 2008;44:103-8

18. Uobe K, Masuno K, Fang YR, Li LJ, Wen YM, Ueda Y, et al. Detection of HPV in Japanese and Chinese oral carcinomas by in situ PCR. Oral Oncol. 2001;37:146-52.

19. Gospodarowicz MK, Brierley JD, Whittekind C, eds. International Union Against Cancer (UICC). TNM classification of malignant tumours. 8th ed. New York; 2017.

20. Shah JP, Gil Z. Current concepts in management of oral cancersurgery. Oral Oncol 2009;45(4):394-401.

21. Omura K. Current status of oral cancer treatment strategies: surgical treatments for oral squamous cell carcinoma. Int J Clin Oncol. 2014; 19:423-30.

22. Brandwein-Gensler M, Teixeira MS, Lewis CM, Lee B, Rolnitzky L, Hille JJ, et al. Oral squamous cell carcinoma: histologic risk assessment, but not margin status, is strongly predictive of local disease-free and overall survival. Am J Surg Pathol. 2005;29:167-78. 23. Brandwein-Gensler M, Smith RV, Wang B, Penner C, Theilken A, Broughel D, et al. Validation of the histologic risk model in a new cohort of patients with head and neck squamous cell carcinoma. Am J Surg Pathol. 2010;34:676-88.

24. El-Naggar AK, Chan JKC, Grandis JR, Takata T, Slootwe PJ. WHO Classification of Head and Neck Tumours. 4th ed. Lyon: IARC Press; 2017.

25. Anneroth G, Batsakis J, Luna M. Review of the literature and a recommended system of malignancy grading in oral squamous cell carcinomas. Eur J Oral Sci. 1987;95:229-49.

26. Johnson NW, Jayasekara P, Amarasinghe AA. Squamous cell carcinoma and precursor lesions of the oral cavity: Epidemiology and aetiology. Periodontol 2000. 2011;57:19-37.

27. Zhang T, Lubek JE, Salama A, Dyalram D, Liu X, Ord RA. Treatment of cT1N0M0 tongue cancer: outcome and prognostic parameters. J Oral Maxillofac Surg. 2014;72:406-14.

28. Garavello W, Spreafico R, Somigliana E, Gaini L, Pignataro L, Gaini RM. Prognostic influence of gender in patients with oral tongue cancer. Otolaryngol Head Neck Surg. 2008;138:768-71.

29. Amaral TMP, da Silva Freire AR, Carvalho AL, Pinto CAL, Kowalski LP. Predictive factors of occult metastasis and prognosis of clinical stages I and II squamous cell carcinoma of the tongue and floor of the mouth. Oral Oncol. 2004;40:780-6.

30. Lindenblatt RC, Martinez GL, Silva LE, Faria PS, Camisasca DR, Lourenço SQ. Oral squamous cell carcinoma grading systems-analysis of the best survival predictor. J Oral Pathol Med. 2012;41:34-9. 31. Almangush A, Coletta RD, Bello IO, Bitu C, Keski-Säntti H, Mäkinen LK, et al. A simple novel prognostic model for early stage oral tongue cancer. Int J Oral Maxillofac Surg. 2015;44:143-150.

32. Jakobsson PÅ, Eneroth CM, Killander D, Moberger G, Mårtensson B. Histologic classification and grading of malignancy in carcinoma of the larynx. Acta Radiol Ther Phys Biol. 1973;12:1-8.

33. Woolgar JA. Histopatological prognosticators in oral and oropharyngeal squamous cell carcinoma. Oral Oncol. 2006;42:229-39.

34. Spiro RH, Guillamondegui O, Paulino AF, Huvos AG. Pattern of invasion and margin assessment in patients with oral tongue cancer. Head Neck. 1999;21:408-13. 
35. Odell EW, Jani P, Sherriff M, Ahluwalia SM, Hibbert J, Levison DA, et al. The prognostic value of individual histologic grading parameters in small lingual squamous cell carcinomas. Cancer. 1994;74:789-94.

36. Woolgar JA, Scott J. Prediction of cervical lymph node metastasis in squamous cell carcinoma of the tongue/floor of mouth. Head Neck. 1995;17:463-72.

37. Weijers M, Snow GB, Dick Bezemer P, Van Der Waal I. Malignancy grading is no better than conventional histopathological grading in small squamous cell carcinoma of tongue and floor of mouth: retrospective study in 128 patients. J Oral Pathol Med. 2009;38:3437.

38. Sawair FA, Irwin CR, Gordon DJ, Leonard AG, Stephenson M, Napier SS. Invasive front grading: reliability and usefulness in the management of oral squamous cell carcinoma. J Oral Pathol Med. 2003;32:1-9.

39. Li Y, Bai S, Carroll W, Dayan D, Dort JC, Heller K, et al. Validation of the risk model: high-risk classification and tumor pattern of invasion predict outcome for patients with low-stage oral cavity squamous cell carcinoma. Head Neck Pathol. 2013;7:211-23.

40. Maleki S, Schlecht NF, Keller C, Diaz J, Moss J, Prystowsky MB, et al. Lymphocytic host response to oral squamous cell carcinoma: an adaptive T-cell response at the tumor interface. Head Neck Pathol. 2011;5:117-22.

41. Chatzistefanou I, Lubek J, Markou K, Ord RA. The role of neck dissection and postoperative adjuvant radiotherapy in $\mathrm{cN} 0$ patients with PNI-positive squamous cell carcinoma of the oral cavity. Oral Oncol. 2014;50:753-8.

42. Woolgar JA. Histological distribution of cervical lymph node metastases from intraoral/oropharyngeal squamous cell carcinomas. British J Oral Maxillofac Surg.1999;37:175-80

43. Sutton DN, Brown JS, Rogers SN, Vaughan ED, Woolgar JA. The prognostic implications of the surgical margin in oral squamous cell carcinoma. International J Oral Maxillofac Surg. 2003;32:30-34. 44. Bundgaard T, Rossen K, Henriksen SD, Charabi S, Søgaard H, Grau C. Histopathologic parameters in the evaluation of T1 squamous cell carcinomas of the oral cavity. Head Neck. 2002;24:656-60. 45. Almangush A, Bello IO, Keski-Säntti H, Mäkinen LK, Kauppila JH, Pukkila M, et al. Depth of invasion, tumor budding, and worst pattern of invasion: Prognostic indicators in earlystage oral tongue cancer. Head Neck. 2014;36:811-8.

46. O-charoenrat P, Pillai G, Patel S, Fisher C, Archer D, Eccles S, et al. Tumour thickness predicts cervical nodal metastases and survival in early oral tongue cancer. Oral Oncol. 2003;39:386-90.

47. Rusthoven K, Ballonoff A, Raben D, Chen C. Poor prognosis in patients with stage I and II oral tongue squamous cell carcinoma. Cancer. 2008;112:345-51.

48. Kademani D, Bell RB, Bagheri S, Holmgren E, Dierks E, Potter $\mathrm{B}$, et al. Prognostic factors in intraoral squamous cell carcinoma: the influence of histologic grade. J Oral Maxillofac Surg. 2005;63:15991605.

Conflict of interest

The authors have declared no conflict of interest exists. 